\title{
Tinjauan Fatwa MUI Nomor 4 Tahun 2005 dan Fikih Munakahat terhadap Praktik Perkawinan Beda Agama di Kecamatan Wonosari Kabupaten Gunung Kidul
}

\author{
Syarifah Sofwah Yahya*, Ramdan Fawzi \\ Bandung, Indonesia. \\ *syarifahsofwahyahya@gmail.com, Ramdan.fawzi1985@gmail.com
}

Prodi Hukum Keluarga Islam, Fukultas Syari'ah Universitas Islam Bandung

\begin{abstract}
The research in this thesis is a type of descriptive research. The data used in this study is secondary data with primary legal material in the form of people who are (subjects) of interfaith marriages. While the approach that the author uses is an empirical juridical approach. The author uses field study data collection techniques (field research) by using interviews and personal documents. Facts that occur in the field, the Civil Registry Office registers interfaith marriages without a court decision. The MUI fatwa states that interfaith marriages are prohibited and the legal consequences of interfaith marriages when viewed from the Munakahat Fiqh will have an impact on marital status, husband and wife relationships, children's lineage and inheritance rights. The results of this study indicate that in the practice of interfaith marriages in Wonosari District, Gunung Kidul Regency, there is legal smuggling by the Civil Registry Office and if the marriage is not legal according to Islamic law then the haraam in the husband and wife relationship occurs, and children born from interfaith marriages it can only be in love with its mother.
\end{abstract}

Keywords: MUI Fatwa, Munakahat Fiqh, Interfaith Marriage.

Abstrak. Penelitian dalam skripsi ini merupakan jenis penelitian deskriptif. Data yang digunakan dalam penelitian ini adalah data sekunder dengan bahan hukum primer berupa orang yang sebagai (subjek) perkawinan beda agama. Sementara pendekatan yang penulis gunakan adalah pendekatan yuridis empiris. Penulis menggunakan teknik pengumpulan data studi lapangan (field research) dengan menggunakan cara wawancara dan dokumen pribadi. Fakta yang terjadi di lapangan, Kantor Catatan Sipil mencatatkan perkawinan beda agama tanpa adanya putusan pengadilan. Fatwa MUI menyatakan keharaman perkawinan beda agama dan akibat hukum perkawinan beda agama apabila ditinjau dari Fikih Munakahat akan berdampak pada status perkawinan, hubungan suami istri, nasab anak dan hak kewarisan. Hasil penelitian ini menunjukkan bahwa pada praktik perkawinan beda agama di Kecamatan Wonosari Kabupaten Gunung Kidul adanya penyelundupan hukum oleh pihak Kantor Catatan Sipil dan apabila perkawinan itu tidak sah menurut hukum Islam maka keharaman dalam hubungan suami istri itu terjadi, dan anak yang dilahirkan dari perkawinan beda agama itu hanya dapat bernasab pada ibunya.

Kata Kunci: Fatwa MUI, Fikih Munakahat, Perkawinan Beda Agama. 


\section{A. Pendahuluan}

Indonesia merupakan negara dengan berbagai suku, bangsa, bahasa, agama dan budaya yang berbeda-beda. Maka perkawinan beda agama sering terjadi di Indonesia. Banyak dari kalangan masyarakat awam, selebritis, sampai kalangan aktifis dan kaum agamawan terdidik yang melakukannya.

Peraturan perkawinan beda agama belum secara tegas diatur di Indonesia. Walaupun Indonesia bukan negara Islam, tetapi mayoritas penduduk Indonesia beragama Islam. Jika dilihat dari Pada Pasal 2 ayat (1) Undang-Undang Nomor 1 Tahun 1974 menyebutkan "Perkawinan yang sah, apabila dilakukan menurut hukum masing-masing agamanya dan kepercayaannya itu" pasal tersebut belum berbicara secara terperinci bagaimana hukum perkawinan beda agama.

Lain halnya dengan UU Perkawinan di atas, bagi umat Islam peraturan perkawinan beda agama di akomodir dalam Kompilasi Hukum Islam Pasal 40 poin (c) dan pasal 44. Dalam Pasal 40 poin (c), menyebutkan "Dilarang melangsungkan perkawinan antara seorang pria dengan seorang wanita dengan keadaan tertentu: (a) karena wanita yang bersangkutan masih terikat satu perkawinan dengan pria lain; (b) seorang wanita yang masih berada dalam masa iddah dengan pria lain; (c) seorang wanita yang tidak beragama Islam". Sedangkan dalam Pasal 44 menyebutkan, "Seorang wanita Islam dilarang melangsungkan perkawinan dengan seorang pria yang tidak beragama Islam". Berdasarkan bunyi ketentuaan 2 pasal tersebut, tidak ada perkawinan yang dilangsungkan oleh agama yang berbeda.

MUI mengeluarkan fatwa atas keharaman perkawinan beda agama pada tanggal 28 Juli Tahun 2005 sebagai penguat lahirnya fatwa tanggal 1 Juni 1980. Penetapan fatwa dengan Nomor 4/MUNAS VII/MUI/8/2005. Isi fatwa tersebut adalah 1) Perkawinan beda agama adalah haram dan tidak sah. 2) Perkawinan laki-laki muslim dengan wanita ahli kitab, menurut qaul mu'tamad, adalah haram dan tidak sah.

Maka berbagai cara ditempuh demi dilangsungkannya perkawinan dan mendapatkan pengakuan dari negara diantaranya: 1. Pagi hari menikah sesuai agama laki-laki, dan siangnya menikah sesuai dengan agama perempuan. 2. Salah satu dari calon pengantin baik laki-laki ataupun perempuan mengalah mengikuti agama pasangannya, lalu setelah menikah dia kembali kepada agamanya. 3. Menikah di luar negeri, kemudian mencatatkan pernikahan itu di Kantor Catatan Sipil. Namun perlu diketahui bahwa dengan dicatatkannya perkawinan beda agama yang dilakukan di luar negeri tidak serta merta membuat perkawinan itu sah di mata hukum Indonesia karena KUA/KCS hanya lembaga pencatat perkawinan.

Perkawinan yang dilangsungkan oleh pasangan yang berbeda agama maka akan menimbulkan dampak yang sangat besar yaitu pada status perkawinan dan berdampak pula terhadap status dan hak-hak anak. Dalam Islam, jika anak perempuan beragama selain Islam yang lahir dari perkawinan orangtuanya yang berbeda agama ibunya beragama selain Islam dan ayahnya beragama Islam maka ayahnya tidak sah menjadi wali nikah dan begitu juga sebaliknya. Dan juga tidak bisa saling waris mewarisi karena salah satu penghalang untuk mendapatkan waris adalah perbedaan agama.

Pada praktiknya, perkawinan beda agama dilangsungkan antara pasangan (SA) dan (MS) dengan dinikahkan oleh Pendeta Gereja Kristen Wonosari dan dicatatkan di Kantor Catatan Sipil dengan Kutipan Akta Perkawinan No. 18/CS.P.5/1999. Perkawinan beda agama tersebut tidak adanya putusan hakim, tetapi Kantor Catatan Sipil Kecamatan Wonosari tetap mecatatkannya sebagai perkawinan yang sah.

\section{B. Landasan Teori}

Fatwa secara terminologi (bahasa) Ibnu Manzhur adalah bentuk dari fatwa yang bermakna muda, baru, penjelasan, dan penerangan. Secara etimologi menurut Yusuf Qardhawi, fatwa adalah menerangkan hukum syara' dalam suatu persoalan sebagai jawaban atas pertanyaan yang diajukan oleh peminta fatwa (mustafti) baik secara perorangan atau kolektif. Fatwa dapat dikeluarkan baik diminta atau tidak tergantung pertimbangan para mufti dalam melihat persoalan yang berkembang. 
MUI adalah sebuah lembaga yang mewadahi ulama, Zu'ama dan cendekiawan di Indonesia. MUI berdiri di Jakarta pada tanggal 7 Rajab 1395 Hijriah bertepatan dengan tanggal 26 Juli 1975. MUI berdiri sebagai hasil Musyawarah Nasional I Majelis Ulama Indonesia yang berlangsung pada tanggal 12 s/d 18 Rajab $1395 \mathrm{H}$ atau 21 s/d 27 Juli $1975 \mathrm{M}$ di Balai Sidang Jakarta. Musyawarah ini diselenggarakan oleh sebuah Panitia yang diangkat oleh Mentri Agama dengan Surat Keputusan No. 28 tanggal 1 Juli 1975, yang diketuai oleh Letjen.Purn.H.Soedirman dan tim Penasehat yang terdiri dari Prof.Dr.Hamka, KH. Abdullah Syafe'I dan K.H.M.Syukri Ghozali.

Fikih Munakahat merupakan hukum perkawinan dalam ajaran Islam, fikih yang membahas tentang hukum perkawinan bagi umat muslim. Hukum perkawinan yang didasarkan pada Fikih Munakahat dilakukan bukan hanya berbasis pada nilai materi, melainkan terdapat nilai-nilai ibadah. Fikih Munakahat meliputi rukun dan syarat perkawinan, perwalian, kewarisan dan apa yang berhubungan dengan perkawinan dalam Agama Islam.

Perkawinan Beda Agama adalah perkawinan antar-agama merupakan hubungan dua insan yang berbeda keyakinan dan diikat dalam satu pertalian yaitu perkawinan. Ada dua unsur pokok yang harus ada dalam definisi perkawinan antar-agama, yaitu keyakinan atau memeluk agama yang berbeda dan diikat dalam suatu hubungan perkawinan.

\section{Hasil dan Pembahasan}

Pada masyarakat Kabupaten Gunung Kidul cukup banyak kasus yang melangsungkan perkawinan beda agama dikarenakan daerah tersebut memiliki pluralitas agama yang relatif tinggi. Pada 35 Tahun yang lalu di Gunung Kidul belum terdapat sekolah dasar seperti sekarang, disana hanya ada sekolah-sekolah nasrani. Dan perkawinan beda agama di Gunung Kidul dianggap biasa karena kedua pasangan itu sama-sama lemah dalam agama. Dan belum ada cara yang ampuh untuk meminimalisir terjadinya perkawinan beda agama tersebut, dikarenakan jika diadakan seperti pengajian yang sifatnya kalau untuk memberikan pemahaman agama yang mendasar sangat singkat waktunya, kemudian menghadiri pengajian yang sifatnya tidak rutin, penceramah pun pembicaraannya tidak mengarah ke keluarga Islam maka sedikit sekali persentase untuk menyadarkan tentang keharaman perkawinan tersebut.

Perkawinan beda agama ini jika ditinjau dari fikih munakahat maka hubungan dari suami-istri ketika masih terikat perkawinan adalah haram dan tidak sah. Dikarenakan dalam hukum Islam rukum perkawinan itu ada 5 yaitu: 1) adanya calon mempelai laki-laki, 2) adanya calon mempelai perempuan, 3) 2 orang saksi, 4) wali, 5) ijab kabul. Dalam perkawinan ini, tidak adanya ijab kabul yang sah menurut syariat Islam. Dan salah satu syarat perkawinan bagi calon mempelai laki-laki dan calon mempelai perempuan adalah samasama beragama Islam. Dalam perkawinan yang terjadi di Kecamatan Wonosari Kabupaten Gunung Kidul ini (SA) seorang laki-laki muslim yang menikahi (MS) seorang perempuan nonmuslim, dari syarat sah perkawinan saja sudah tidak terpenuhi. Maka perbuatan hubungan suami-istri selama dalam hubungan perkawinan menjadi haram dan tidak sah. Status anak dalam perkawinan yang tidak sah hanya bernasab kepada ibunya. Maka ayahnya tidak dapat menjadi wali bagi anak perempuan yang beragam Islam. Dan perbedaan agama adalah salah satu keadaan yang menghalangi dapatnya hak waris.

Dalam tinjauan fatwa MUI juga demikian, fatwa yang ditetapkan oleh MUI sudah ditimbang dengan berbagai ayat-ayat al-Quran dan hadits Nabi. MUI menimbang salah satunya dari QS. al-Baqarah ayat 221. Yaitu Allah melarang laki-laki muslim menikahi perempuan musyrik sebelum perempuan itu beriman kepada Allah. Dan MUI mengambil kaidah fikih "mencegah kemafsadatan lebih utama dari mengambil manfaat". Dalam perkawinan beda agama ini dilihat lebih banyak kemafsadatannya. Bisa berdampak pula kepada psikologis seorang anak, mereka akan bingung untuk memilih agama yang akan dianutnya.

\section{Kesimpulan}

Praktik Perkawinan yang terjadi di Kecamatan Wonosari Kabupaten Gunung Kidul antara 
pasangan (SA) yang beragama Islam dan (MS) yang beragama Kristen yang menikah di Gereja Kristen Jawa Wonosari dianggap tidak sah karena melakukan perkawinan beda agama di wilayah Indonesia dan tidak menggunakan cara yang dianggap akan diakui oleh negara, seperti harus menikah di luar negeri terlebih dahulu. Dan pencatatan perkawinan yang dicatatkan di Kantor Catatan Sipil Kecamatan Wonosari Kabupaten Gunung Kidul dianggap telah melakukan penyelundupan hukum dan tidak ada penegakan hukum oleh Kantor Catatan Sipil karena sejatinya Kantor Catatan Sipil hanya mencatatkan perkawinan diluar Agama Islam bukan perkawinan beda agama. Walaupun Kantor Catatan Sipil mencatatkan perkawinan beda agama harus ada putusan pengadilan yang sah, tetapi dalam kasus ini tidak ada putusan pengadilannya.

Berdasarkan analisis tinjauan Fikih munakahat terhadap kasus perkawinan beda agama ini, praktik perkawinan antara laki-laki yang beragama Islam dengan perempuan yang beragama non-Islam dianggap tidak sah dan hubungan suami-istri yang dilakukan selama ini menjadi perbuatan yang haram. Berdampak pula kepada hak nasab anak tidak dapat dinasabkan kepada ayahnya dan pada hak waris karena perbedaan agama termasuk keadaan yang menghalangi seserang mendapatkan warisan.

Berdasarkan analisis tinjauan Fatwa MUI Nomor 4 Tahun 2005 terhadap kasus perkawinan beda agama ini dianggap haram dan tidak sah. Walaupun fatwa bersifat tidak mengikat tetapi perkawinan beda agama ini akan berdampak pada rusaknya tujuan-tujuan pensyariatan Islam dan tujuan awal perkawinan yang menjadi keluarga yang sakinah, mawaddah, dan warahmah lama-lama akan luntur karena perbedaan dalam beribadah.

\section{Daftar Pustaka}

[1] (M), Wawancara, 8 Juli 2021. (t.thn.).

[2] Arifin, Z. (t.thn.). Perkawinan Beda Agama. Jurnal Lentera, 145.

[3] Hamzah, M. M. (2017). Peran Dan Pengaruh Fatwa MUI Dalam Arus Transformasi Sosial Budaya di Indonesia. Jurnal Studi Agama, 132.

[4] Indonesia, H. F. (t.thn.). Perkawinan Beda Agama.

[5] Indonesia, T. P. (1995). 20 Tahun Majelis Ulama Indonesia. Jakarta: Majelis Ulama Indonesia.

[6] Mujahid, I. (2019). Transformasi Fikih Munakahat Tentang Hukum Menikahi Wanita Ahli Kitab Ke Dalam Kompilasi Hukum Islam Pasal 40 Huruf (C). Istidlal, 82.

[7] Pasal 2 ayat (1) Undang-Undang Nomor 1 Tahun 1974 Tentang Perkawinan. (t.thn.).

[8] Simanungkalit, R. (2020). Pendampingan Pastoral Dengan Paradigma Spiritual Care Pada Pernikahan Beda Agama. Jurnal Teologi “Cultivation”, 19. 